\title{
University vs. Society in a Period of Nation Building: The Hebrew University in Pre-State Israel
}

\author{
Uri Cohen
}

\section{ABSTRACT}

This article examines the process by which the Hebrew University of Jerusalem was established, from 1925-1948, during the period of the British Mandate in Palestine. It finds that the World Zionist Organization was deeply involved in this project, viewing a university as an important building block in the creation of a Jewish nationality in the Land of Israel. But alongside this Zionist role, Jewish communities around the world, particularly in Europe and the United States, also played an important academic and financial role in the establishment of the Hebrew University. This study reveals that, in contrast to the common pattern of close cooperation that is characteristic of relations between academic institutions and cohering national elites, the Hebrew University consistently pursued an academic policy that generated acute tension vis-à-vis the political leadership in Jewish Palestine. The University deliberately nurtured an elitist policy while rejecting attempts to make it service the general public needs, as defined by the local political leadership. Rather, the University saw its central role as being a "university for the dispersed nation," that is, a university for all of the Jewish people.

\section{RÉSUMÉ}

Cet article examine le processus au cours duquel l'Université hébraïque de Jérusalem fut établie de 1925 à 1948, alors que la Palestine était sous mandat britannique. Il montre que la World Zionist Organization fut profondément impliquée dans le projet, considérant l'université comme une importante composante de la création d'une nation juive en terre d'Israël. Mais à côté de ce rôle sioniste, les communautés juives du monde entier, particulièrement celles d'Europe et des États-Unis, jouèrent aussi un rôle académique et financier important dans l'établissement de l'Université hébraïque. Cette étude montre que, par opposition au modèle habituel de l'étroite coopération qui caractérise les relations entre les institutions académiques et les élites nationales unies, l'Université hébraïque poursuivit immanquablement une politique académique qui généra une vive tension au sein de la direction politique de la Palestine juive. L'Université alimenta délibérément une politique élitiste tout en rejetant les tentatives de la mettre au service de l'intérêt public général, comme il avait été décidé par la direction politique locale. Au lieu de cela, l'Université se considéra comme "une université de la diaspora ", soit une université pour tout le peuple juif. 


\section{Introduction}

The Hebrew University of Jerusalem (HUJ) was founded in 1925, becoming the leading academic institution in Palestine during the period of the British Mandate. The University enjoyed a monopoly over most of the fields of academic research and teaching in which it was active. A monopoly that gave it a clear advantage over the four other institutions of higher learning in existence in Palestinian at that time: the Technion in Haifa, which specialized in engineering and architecture and was founded in 1924; The Ziv Institute (later the Weizmann Institute) in Rehovot, which focused exclusively on research in the natural sciences and was founded in 1932; the Law Classes in Jerusalem, which operated under the aegis of the British mandatory authorities starting in 1920 and trained lawyers; and the School of Law and Economics in Tel Aviv, which was a private academic institution established by the city of Tel Aviv in 1935. ${ }^{1}$ The community's political leadership also saw the Hebrew University as society's academic leader. Thus, with the founding of the state of Israel in 1948, David BenGurion, who was then serving as acting Prime Minister, issued an official letter to University officials in which he pledged to maintain the institution's premier standing in the country. ${ }^{2}$

By 1948, the HUJ was comprised of a faculty of humanities, a faculty of science, a pre-faculty of medicine, a school of agriculture, a department of education, and the Hebrew University Press, as well as the Jewish National and University Library, which contained almost 500,000 volumes. The University had been founded as a research institution consisting of three institutes devoted respectively to chemistry, microbiology and Jewish studies. These functioned solely as research institutes, but the question as to whether the University should become a teaching as well as a research institution was the subject of public discussion for a number of years. As a result, teaching was only introduced in 1928, at which time the University enrolled 250 students. By 1948, their numbers had grown to 1,027 , in addition to the 190 members of the academic faculty. By 1948, the HUJ had awarded 842 degrees to students. ${ }^{3}$

However, from its very inauguration until Israel's independence in 1948, the HUJ's relations with both Jewish society in Palestine and the World Zionist Organization (WZO) were ambivalent in nature. The WZO often sought to function as the central authority directing and shaping the University's academic activity. Prominent circles among the HUJ's founders resisted these demands, a position that was supported and upheld by non-Zionist Jewish communities around the world, whose consistent support for HUJ constituted the university's principal base of power. These tensions continued throughout the pre-independence period and found public expression both in university speeches and publications, and in the consistently harsh criticism directed at HUJ by sectors within Jewish society. ${ }^{4}$

The central aim of this article is to re-examine the relationship that took shape between a national movement, whose goal was the establishment of a sovereign state, and a university, which was founded and operated under the aegis of that same national movement. ${ }^{5}$ In general, a period of state building is characterized by a strong mutuality 
and close cooperation between the national movement and various cultural projects that bolstered the ideological foundations of the movement and advanced its views among the public at large, particularly during times of acute social tension. ${ }^{6}$ In most instances, universities constitute a central arena in which the political and intellectual elites leading the emerging nation define themselves. The close mutuality existing between nationalist ideology and the university originated in Europe, but has since spread to most of the new nations established in Asia and Africa in the twentieth century. ${ }^{7}$

Modern European universities received significant impetus from a nationalistic agenda that defined their principal objective to be a strengthening of the nation and the nation state, not at the least by assisting in its practical construction and in its political definition. This does not contradict the role of developing views concerning higher education. As the historian, John E. Craig wrote, " $[\mathrm{t}]$ he story of the transformation of the European university in the nineteenth and early twentieth centuries is essentially a story of how higher education came to be adapted to the requirements of emerging nation states - to their requirements of bureaucrats and teachers, for political socialization, for advanced technology, and for cultural identity and prestige."

Anthony D. Smith claimed that the era of nationalism, and especially of nation building, witnessed the establishment and expansion of universities and technical institutes, which now gave a whole new generation of future community leaders their training. As a result, a new type of society emerged led by a state that increasingly relied on scientific knowledge in its bureaucratic operations, and thus required a new breed of leadership that combined secular expertise with literacy and a confident rationalism. Universities became the center of national memory and definition as they replaced the church and priesthood as the central institutions of cultural life.

The movement to establish a Jewish university dates from the early days of the twentieth century. A suggestion was made at the Zionist Congress of 1901 to create a university that would serve a role in the Zionist colonization program in Palestine. In July 1902 details of this proposal were published in a pamphlet that called for the establishment of a Jewish university to advance the cultural and technological development of a Jewish community in Palestine, an essential complement to the political mobilization necessary for establishing a national state. ${ }^{10}$ The authors of this pamphlet, Martin Buber, Berthold Feiwel, and Chaim Weizmann, based much of their plan on the culture of the German university, where they had been socialized academically and where Buber and Weizmann had established themselves professionally. All three had been immigrants from Eastern Europe. It was in Central Europe where they received their training and developed their ideas about how universities could be organized and what they might accomplish. This, in fact, was the most common biographical experience of those who would join the faculty of the HUJ. ${ }^{11}$

The present article consists of two parts, both of which examine the seemingly paradoxical relationship between a political force seeking to realize its sovereign ambitions, and a cultural force established to support the state-building project that nevertheless exhibited a high degree of academic autonomy and consequently posed a permanent challenge to the political leadership. The first part examines the criticisms 
by political parties and important ideological movements in pre-state Jewish society on the direction HUJ was taking. These critiques found expression even before the university was founded and were primarily born of opposition to the creation of an elitist research university that would develop itself in accordance to the cultural needs of the international Jewish community. After its founding, the national political leadership demanded that the University devote itself to satisfying the professional needs of Jewish society in Palestine, in addition to the needs of Jewish students who were being pushed out of European universities. The second part of this article will examine the institutional and intellectual conditions that made it possible to found a university that operated in open conflict with the society in which it was located. It will be argued that the failure of national political forces to dictate their agenda to HUJ in fact contributed to a conflictual relationship and to incessant criticism. It also made possible a unique academic model, which encouraged the creation of a synthesis between the national movement and the mobilization of numerous communities around the world who were not clearly identified with the Zionist movement but who now did their best to support the first Jewish university. ${ }^{12}$

\section{Part A}

\section{The Political and Social Attitudes Toward the HUJ}

Ideologues and politicians were critical of the Hebrew University of Jerusalem (HUJ) from its very inception. They criticized it as being an institution of study, research and teaching, and argued that the university was detached from society's political establishment, which was then in its formative stages. They complained the HUJ did not represent this establishment's worldview and that moreover, it did not bestow this worldview with an academic seal of approval, which is, granting either intellectual or "scientific" legitimacy. ${ }^{13}$ They further contended that only strict and direct control of the HUJ's governing institutions by the Jewish society could effect the desired changes in the university's development.

It is evident that the principal political movements in Jewish Palestine were critical of efforts to establish a university even in the planning stages, prior to its opening in 1925. ${ }^{14}$ As a central cultural institution, the university was seen to be a potential competitor for leadership in the Jewish national revival in Palestine, particularly so by the labour movement which espoused a national vision of agrarian settlement. ${ }^{15}$ Criticism escalated as political and ideological groups began to realize that HUJ intended to operate as an independent entity, and especially as it began to shape itself into an independent sector of society that would debate, criticize and even reject decisions made by the national and political leadership. This attack on the university was strong and persistent, continuing throughout the period prior to statehood.

This section of the article seeks to closely examine the views espoused by the central Zionist political movements and groups within Jewish society regarding HUJ. These include the Zionist Revisionist party, the civic leadership, the labor movement, and religious circles. ${ }^{16}$ 
As noted above, the notion of establishing an academic institution in Palestine faced opposition well before the first brick was laid. At the eleventh Zionist Congress in 1913, Zeev Jabotinsky, the charismatic leader of the Revisionist movement, became a member of the committee charged with advancing the creation of a Hebrew university. ${ }^{17}$ However, upon realizing that Chaim Weizmann was primarily concerned with establishing a research institute rather than a training and teaching facility for Jewish students from Europe, Jabotinsky became highly critical of the project and wrote a letter of protest he addressed to the Zionist Federation in Berlin in which he "demanded that the plan for 'institutions' ... be rejected and the principle for professional institute [guide] the founding of a school of higher learning for students."18

Numerous labour movement leaders expressed their opposition to the founding of a university in Mandatory Palestine. In 1913, Avraham David Gordon, wrote that he was worried that a class of parasites may take shape in Eretz Yisrael (Palestine), one that did not engage in physical labour, which would replicate Jewish life in the Diaspora and consequently emasculate the Zionist revolution. He objected to the enlistment of academics in any future federation out of fear that they would undermine those pioneering elements encouraging a return to the land. ${ }^{19}$ Yoseph Aharonovitz, a leader of Hapoel Hatzair (The Young Worker), was warned of the dangers of building a university that would be identified with Jewish Palestine, but would be controlled by forces outside of Palestine, namely, the Jewish bourgeoisie. He believed that a successful university would cause real harm to a true Zionism and he demanded that the Zionist Federation first attend to furnishing agricultural instruction to those who work the land, a priority which was more consistent with national needs. ${ }^{20}$

Elazar Vulcani also objected to the principles as presented by Chaim Weizmann, Martin Buber and Berthold Feiwel in 1902. He argued that there was no reason to establish a university in Palestine that would, in essence, cater to Jewish students who could not matriculate, for one reason or another, in European universities. He claimed that a university would divert funds that were needed for more important goals, such as the purchase of land. "Every penny spent on spiritual institutions, instead of investing in land, strengthens the enemy and brings our demise that much closer. A nation dying for lack of land does not build spiritual castles in thin air." ${ }^{21}$ In August 1913, the Fourth World Committee of Poaley Zion (Workers of Zion) met in Krakow, Poland, and decided that the "current economic and cultural conditions, and the state of the Jewish society in Palestine, cannot, under any circumstances, support a Hebrew University in Jerusalem.” 22

\section{A-1: Revisionism - The Jewish Right Wing in Palestine}

After the founding of HUJ, the Revisionists, at first under the leadership of Zeev Jabotinsky and then Menachem Begin, made it clear that the university was developing in a manner wholly inconsistent with national needs. Jabotinsky attacked every facet of the HUJ's activities. He was critical of the large, festive inaugural ceremonies where the podium was shared by leaders of the Zionist movement and British officials who were implicated in the White Book policies. ${ }^{23}$ 
"I would like to hope," wrote Jabotinsky, "that this tactless, multilateral display will not end up costing us dearly, will not result in clashes in Eretz Yisrael and will not resonate with unpleasant echoes in the world press ... this trick is an example of ... unforgivable frivolity." 24 Jabotinsky thought that the title given to the ceremony was misleading since it referred to the establishment of research institutes that could not, in truth, be called a university. He was of the opinion that a new, national university be established; one that would attract thousands of Jews who preferred Jerusalem to Europe and that would create a Hebrew science written in Hebrew. He believed, however, that the research institute proposed by HUJ would be populated by Jewish scientists who were graduates of foreign universities and versed in foreign literature. Thus, while Jerusalem was the site of this facility, declared Jabotinsky, "which is quite pleasant for us, there was nothing of global significance in the event." 25 Jabotinsky proposed adoption of the Lithuanian university model by which its founders had recognized a full range of national and cultural issues, turning the university into a revolutionary springboard for the Lithuanian people. He viewed HUJ, in contrast, as something of a fraud, two small laboratories that offered no teaching and had no students. This could only provoke the criticism of anti-Zionists who sought to have the Balfour Declaration rescinded since they would see HUJ as a form of Potemkin villages, "a façade without foundations and not even a floor and ceiling... Who needs it? Couldn't research facilities be opened without all the commotion?"26 Jabotinsky was no less concerned that the Arabs would view the inaugural ceremonies as a boisterous provocation; an unnecessary provocation since the issue was not essential to Zionism but its consequences could become dire. $^{27}$

Jabotinsky's harsh views were attacked by a Warsaw Jewish newspaper argued that of all the people, Jabotinsky, attributed great importance to policy and ceremonies, therefore he should appreciate the significant political impact of the university's inauguration ceremonies. Jabotinsky reiterated criticisms in his rebuttal, claiming that the ceremonies had damaged the Zionist cause. He said such a political declaration as establishment of the HUJ could be meaningful if one of two conditions were met: first, the political act should reveal the inner forces at work within the nation that would force a change in British policy; second, the act should define a specific goal for one's struggles, thus according it a moral as well as a political dimension. But, Jabotinsky asserted that "the importance of the event on Mt. Scopus was nil on the first account, and less than that on the second." 28 The moral failure in the university's creation was manifested in the fact that it did not encourage large-scale Jewish immigration to Palestine. It was subsequently nothing but "an empty shell." According to Jabotinsky, vehement anti-Zionist propaganda in England and Palestine was based on the claim that Zionism did not actually seek a vast influx of Jews into Palestine but was far more concerned with creating, according to Ahad Ha'Am's theories, a spiritual center for world Jewry.

In 1925, shortly after the founding of HUJ, Jabotinsky demanded that the research institutes be immediately replaced with two specializations; "Hebrew public service" and "oriental trade." ${ }^{29}$ The first faculty would specialize in training administrative personnel who would then constitute the foundation for the administrative structure of the future state. The second field would focus on developing trade in the Middle East 
and Asia through the sale of goods produced in Palestine. ${ }^{30}$ Jabotinsky was strictly opposed to academic faculties that required large budgets and were of little public value, such as medicine, engineering, or the natural sciences.

Several years later, in 1932, Jabotinsky presented his view that the university should focus on those fields that would directly serve the goal of state building, arguing that a faculty in oriental trade would be a step in that direction. He also called for the establishment of an institute for social work that would organize the Jewish people, allowing those of the younger generation who wished to devote themselves to "national Jewish work" to find "appropriate training." ${ }^{31}$ He suggested that since there was little point in waiting for the leadership of HUJ to initiate such a project, an institute of higher learning be founded, separate from the university, devoted to addressing tasks ignored by HUJ.

All parties and groups on the right wing of the political spectrum joined Jabotinsky in his opposition to the policies of HUJ. They demanded that members of the academic faculty whose behaviour violated "appropriate" national criteria be dismissed. Thus, when HUJ Rector Bergman lectured in Warsaw, Revisionists distributed pamphlets that called for his dismissal, as well as the dismissal of the university's President, Magnes. ${ }^{32}$ Materials that were distributed on the eve of elections to the Student Organizing Committee by the national student organizations "Yavne" and "Yodfat" expounded on their views of HUJ: "Nothing has changed here. The same Brit Shalom [a peace movement] spirit of national inferiority still prevails. Our Priests of Science still largely deny our national goals or are oblivious to them, living, as they do, in some sort of Olympian serenity.... The university must expand, add new faculties, and [be more than] a 'research facility.' The university must be national...train[ing] teachers for the people and provid[ing] guidance to the yishuv [Jewish society in Palestine]...be imbued with the knowledge of their people and zealous of this knowledge.... The university must be a center for a struggle on behalf of national rights and a free, independent life, on behalf of national culture, and not a habitat for defeatist theories born of exile and assimilation." 33

The student newsletter Ladror ${ }^{34}$ (Toward Freedom), which had a Revisionist orientation, published short, anonymous pieces on current events, addressing, among other issues, HUJ, its faculty and the danger posed by the spread of its ideas. ${ }^{35}$ Another article presented a sharp attack on HUJ President Judah Magnes who, together with other university employees, so the writer claimed, ignored the news of the persecution and murder of European Jews arriving from Poland. "Any other nation would have denounced this man Magnes as a traitor and treated him accordingly; we give him the presidency of the university.... It is not in the hands of Magnes and the likes of him that the Jews of the Diaspora have put their fate.... Magnes should be swept into oblivion - together with his holy entourage - and out of our public arena." ${ }^{\text {36 }}$

Menachem Begin best summarized the Revisionist attitude towards HUJ. Like Jabotinsky, Begin, who was the leader of the underground military organization Etzel, criticized the direction that HUJ had taken, sharply denouncing the political and ideological positions common to its faculty members. Begin decried them as denizens of what he called Olympus (alluding to the university's location on the top of Mount Scopus in Jerusalem), detached from Jewish life in Palestine. This is what shaped their 
"HUJ-scoped morality." The attitude of "the ex-cathedra know-it-alls," according to Begin, was informed by a readiness for compromise on the most important issues for Jewish society in Palestine, compromise with the British government and with the Arabs. Members of the academic world had removed themselves from their society, Begin continued, becoming "scope-totting scouts.... There is nothing that will shake up their supercilious, philosophical, critical position. They are not part of anything that happens down here on earth. They reside up there, high on their moral Olympus, from whence they sound their soft, clear, reproving voice." ${ }^{37}$

\section{A-2: The Liberal Wing of Jewish Society}

Liberal circles perceived HUJ as central to the national-cultural mission and accordingly paid constant attention to all that transpired there. Any development that seemed like it would bring the university closer to Jewish society in Palestine was cause for celebration. At the same time, during the early period of HUJ's existence, harsh criticisms were to be heard from these quarters directed at the university. The pronounced ambivalence of the Farmers' Organization vis-à-vis HUJ was to be traced, in part, to the organizations anti-intellectualism, that is, its view of immigration to Palestine as being directed to strengthening the bond between Jews and the land through intensive agricultural work. Such a bond was perceived as being opposed to the purposes of higher education. It followed, then, that the new Jewish society did not need to discover scientific talents - individuals would do this on their own. Zionist education, rather, should be limited to elementary schools where young people would learn enough to turn them into farmers. One could, then, forego secondary school since such studies were seen as preparing youth for higher education. "Our reality is Eretz Yisrael-and with this understanding we must prepare the new generation for its destiny. Elementary education must awaken them toward the plow and pruning shears, not toward residence in ivory towers .... We do not lack intelligent people - give us those who will use a plow and want to tend orange groves in a remote corner of Asia." 38

Articles published in the press by liberal leaders occasionally compared HUJ to the Technion in Haifa, which, they claimed, trained young people for real life, thus proving its worth. True, the Technion trained more engineers than society needed, but it should not be restricted or attacked since these engineers were in a position to spearhead their way into the technologically disadvantaged neighbouring Arab countries, which would consequently strengthen the Jewish hold on Palestine. In contrast, HUJ ignored what should be an important goal, namely, providing the young generation with scientific training. "Insofar as a university is related to teaching the thousands of young people who remain here - we still have no such an institution. The university grows every year, and every year dozens of graduates of our handful of high schools leave the country to 'further their studies' overseas." 39 Smilansky claimed that HUJ adopted such abstractions as "Judaism" and "humanism" causing it to lose track of its true goal the Jewish desire to live the life of a normal nation, free of historical missions. While Zionism sought to create Jews who were rooted in the land and the Hebrew language, HUJ seemed to send them away to foreign countries and to other tongues. ${ }^{40}$ 
At the second HUJ commencement ceremony, Smilansky expressed satisfaction at the fact that HUJ was gradually turning into "a regular school" not exclusively focused on research. However, he insisted, it must dispense with "useless" Jewish and Oriental studies in order to accommodate the many young European Jews who were seeking admission to HUJ in order to pursue practical studies. ${ }^{41}$ Such studies would play a part in reshaping the image of Jewish immigrants to Palestine. Furthermore, it was of pressing importance that a faculty of agriculture be established since "the future of the Jewish people is in agriculture." 42 A demand was also made of HUJ to open technological institutes. ${ }^{43}$ Critics claimed that focus on research rather than teaching hindered the immigration of European students, especially from Germany, to Palestine. ${ }^{44}$ To rectify this situation, "it is imperative [that HUJ] change to instruction and teaching, a step requiring complete re-organization; perhaps even that of the Board of Governors." 45 This was one of the first instances of a public demand for change within HUJ's governing bodies that would give society greater influence over the institution. With that aim in mind, liberal circles sought to limit the power wielded by HUJ Chancellor Judah Magnes by transforming the institution's sources of funding. "The time has come that university issues will be the interest of the broad Jewish population, and concern for its existence will be removed from being a burden carried by a few to one carried by the entire nation, assuming that this will also give the nation an opportunity to affect HUJ spirit and direction." ${ }^{46}$

The goal of such institutional change was to end HUJ's independence and its ability to plot its own course. Smilansky claimed that, "a vast abyss of harsh reality lay between the multitudes and Mount Scopus." ${ }^{77}$ This abyss was formed because the university lacked any guiding principle; "the science center is not fulfilling its duties if it cannot create the largest number of anonymous academic personnel who disseminate scientific achievements to the people." 48

After the early 1930s, vast waves of immigrants began to arrive in Palestine, particularly from Poland and Germany. These immigrants soon changed the character of Jewish society. Between 1930 and 1935 the Jewish population grew from 164,796 to $355,157 .{ }^{49}$ Liberal circles became convinced that HUJ had altered its position vis-a-vis society. The founding of the new Hadassah Hospital was seen to be an important demonstration of a new connection, one achieved not by displacing Arabs but by bringing modern medicine that would improve the living conditions for all. Because the hospital was part of the university, it was considered a "breath of fresh air to our university, whose first years, erroneously, were spent in study and theory, without any direct, live contact with the Jewish society and its needs. This year's developments - the thousand students admitted, the vocational departments that were opened or expanded, the new professors hired - all testify to a new and valuable change of direction." 50

The year 1936 saw a reorganization of the university's administration, which now included an Executive Committee, whose members included prominent figures from the Jewish community in Palestine. The Executive Committee successfully expanded the university by finding a place for Jewish scholars and students who had left the beleaguered countries of Central and Eastern Europe. In that same year, diplomas were 
granted for the first time by the faculty of natural sciences. The seventeen recipients of the new M.Sc. degrees were seen as part of a significant move toward meeting social needs. $^{51}$

Dr. Moshe Glickson, editor of the daily liberal newspaper, Ha'aretz, and the head of the Tel Aviv Friends of Hebrew University Association, ${ }^{52}$ presented his position on HUJ at a discussion held by the Hapoel Ha-Zioni committee in 1937 . The idea that a university "is a luxury" - an idea still prevalent overseas - was "completely erroneous, not only from the point of view of constructing our national education.... The Hebrew University is the crowning glory of this construction, and it is destined to fulfill an important spiritual and practical role in the actual building of the nation." 53 Glickson was opposed to the preference for research over teaching and was especially dissatisfied that "professors who want to work in Jerusalem can act like 'tourists' in our culture. One cannot be a professor at the Hebrew University without having roots in Hebrew culture and the Hebrew language... hopefully, this will change." ${ }^{54}$

\section{A-3: The Labour Movement}

In the years prior to the Second World War, criticism directed by the labour movement towards HUJ primarily focused on the university's underlying assumptions regarding relations with the Jewish Diaspora. At the same time, the labour movement welcomed the assistance extended by world Jewry to HUJ, particularly the monetary contributions, since it was felt that science would advance the cause of nation building. However, critics argued that the notion of a Hebrew university had not truly penetrated Central European and East European Jewry, who had from the beginning perceived such a project as obscure. Jewish European youth rushed to European universities while only a very few went to Jerusalem. Active support of HUJ came primarily from the United States, due to Magnes's efforts in enlisting a number of wealthy donors who contributed large sums of money. However, young American Jews did not come to study in Jerusalem. Labour movement leaders understood this to be an indication of a schism between HUJ and the Diaspora, not to mention between HUJ and Jewish society in Palestine.

In 1937 HUJ counted among its faculty approximately one hundred scientists and over seven hundred students, all this achieved without the support of the British government or the World Zionist Organization. Nevertheless, despite this success, critics claimed that the university's ties to Jewish society were weak, even after a decade of existence. They considered the aim of HUJ to be "the ultimate synthesis of reviving the nation and its culture in tandem. Without a university, a nation lacks culture and spirit. However, a university without a nation is equally lifeless." ${ }^{55}$ Critics in the labour movement believed that the university was obligated to focus on "education for the people," Education was meant to reach all levels of the population throughout the country. At the same time, the HUJ's democratic foundation needed to be expanded by including more representatives from society at large in the university's management.

Berl Katznelson, ${ }^{56}$ Editor of Davar, (the daily newspaper of the labour movement and Histadrut Federation of Workers) was wary of "the charity of benefactors." 
Although conceding that, "we would not have witnessed the building of the university" without such help. He maintained that a national project could not depend on the "wishes and perceptions" of foreign donors, especially when they are geographically and mentally removed from the nation's needs and from the building up of the land. ${ }^{57}$ Katznelson believed that the reliance on overseas donors led to an ultimately futile rushing back and forth between fragmented sources that would never achieve any unity. To rectify this problem, control of HUJ should be gradually shifted from the Diaspora to Jewish society in Palestine.

Katznelson supported the recommendations of the 1935 Herzog Committee, which called for the creation of an Executive Committee for the university that would periodically convene in Palestine in order to closely supervise HUJ. In his mind, such a change paralleled developments within the Zionist movement in general, which had held its early congresses overseas and then later moved them to Palestine. Katznelson also believed in the need to grant independence to the faculty. This would serve to limit Magnes's centralized authority. Katznelson called for the establishment of a teachers training program, in spite of objections from abroad, ${ }^{58}$ as well as limiting the influence of scientists recently arriving from Germany. The latter was needed in order to lessen tensions within society, as Katznelson argued; "we are creating workplaces not only for those who came from Germany. The university cannot be the exclusive domain of people from one part of the Diaspora, and cannot bear the monotonous seal of one tribe alone." 59

In the mid-1930s, Katznelson dismissed the teaching vs. research debate as irrelevant. He believed that the real issue was about the nature of HUJ: Was it to function as a local university, adapting itself to society's needs, or was it to be a pallid, inferior facsimile of European universities? His position was clear. It found expression not only in the demand for teacher training but for agricultural studies as well. "What is the value of a university for a nation whose very revival is on the land?" ${ }^{60} \mathrm{He}$ also complained about the delay in creating civil service studies that were needed to "elevate the quality of public work and the dignity of the public worker." Finally, he demanded that HUJ be more involved in Tel Aviv and in other localities. "The finest day in the life of the Hebrew University will be the day it begins giving regular classes and seminars in the heart of the Jezerel Valley." ${ }^{61}$

After word of the destruction of European Jewry reached Palestine, Katznelson discerned a new problem; "All that we had ... students, professors, young scientists ... all have gone, all have perished." ${ }^{2}$ And so, Jewish society could only rely on itself to build the country. He called for renewed efforts on behalf of the workers, led by the Histadrut, to gain control of HUJ. He foresaw no possibility that the university would draw closer to society at large. Katznelson repeated these views of a dichotomy between HUJ and Jewish society in a speech he delivered in September of 1944, referring to the local interests of the pioneering farmer as opposed to the cosmopolitan interests of scientists, a gap he proclaimed to be "unbridgeable." ${ }^{3}$ He saw in pioneering not only personal fulfillment, but an ideological system imprinting itself upon a historical period and allowing for innovation, revolution and creativity. That part of society devoted to 
scientific and spiritual matters endangers the pioneering ethos. This speech was made upon the enrollment of the scientific faculty of HUJ as members of the Histadrut, a development that he likened to "an entrance hall to something much larger...clarifying to the scientific and professional intelligentsia that there is no life in Eretz Yisrael without the efforts of pioneers." 64

David Ben-Gurion ${ }^{65}$ adopted a similar attitude and sought to mobilize the University on behalf of state building, a relationship he perceived to be the essence of Zionism. However, David Ben-Gurion also exhibited a high regard for science, telling a group of students in January 1944 that "it is the duty of this audience to mobilize Jewish science to create and build the Jewish state.... A state needs agriculture, industry, seafaring, and an army, none of which can be achieved without science." He contended that the common denominator of Zionism and science was the freedom and pursuit of truth. "Science is one of the most powerful weapons of Zionist fulfillment." ${ }^{66}$ In September 1946, addressing the sixth MAPAI [Israeli Worker's Party] convention, Ben-Gurion emphasized the urgent need to broaden scientific abilities, stating that material resources and the nation's finest talents should be devoted to that purpose. This represented a change of attitude towards the HUJ. Until that time, the labour movement had cast doubt on the usefulness of scientists, if not of the university in general, preferring the ideal of farming and physical labour. Ben-Gurion now declared that it was science and the university, which constituted the foundation for pioneering as, "our scientific abilities and technological progress may - more that anything else - determine our future." ${ }^{67}$

It is quite possibly that the technological developments of World War II, particularly those related to nuclear physics, were what led Ben-Gurion to conclude that science would be an important means of advancing, if not preserving, the nation. In preceding decades, when HUJ came under attack for maintaining its independence and for not serving the immediate needs of the local population, it insisted on its status as an institution shaping itself according to the needs of all the Jewish people, serving as the only university of the Jewish Diaspora.

\section{A-4: The Ultra-Orthodox and the Religious Zionists}

Ultra-Orthodox circles were also highly critical of HUJ, the main thrust of their attacks being directed at the university's involvement in religious matters, particularly biblical research. They claimed that a solemn promise had been made at the inaugural ceremonies declaring that HUJ would protect the holiness of the Torah and not engage in the critical study of the Bible. In return, the university received the blessing of Rabbi Kook. ${ }^{68}$ Religious circles were especially angry with Martin Buber, who claimed that "Christianity is the true Judaism" along with Professor Bergman, who agreed to publish a booklet that proposed the Book of Esther be removed from the Bible. HUJ also incurred Ultra-Orthodox wrath as a result of the funds it devoted to the study of Islam and the collection of texts and artifacts relating to Muslim tradition and poetry.

There were also complaints about HUJ President Judah Magnes, a Reform Rabbi who allegedly allowed dangerous ideas to circulate in the university. Magnes's views of the relationship between Judaism, Christianity and Islam were seen as denying the 
uniqueness of Judaism. The Ultra-Orthodox further complained that HUJ had assumed a "role that could not and would not succeed - to combine Divine Hebrew culture with secular humanism, without differentiating between them ... as two equal partners, as two human creations. But Judaism is at a disadvantage, as [the university] views it as a culture that is old and distant from life, whereas humanism is the latest word on life." ${ }^{69}$ It followed, then, that HUJ employed a large number of German scholars who had long since left the path of the Torah and who looked upon Jewish tradition from a distant perspective corrupted by other cultures.

In contrast, religious Zionists sought to play a part in HUJ activities and they completely rejected the Ultra-Orthodox break with the university. Yavneh, a religious student's organization, was established in 1929 and numbered some 120 members by 1938; "vibrant youngsters who have, in their soul, unified the two worlds...Torah and science." ${ }^{70}$ Yavneh gained the support of the religious public and participated in events led by Chief Rabbi Herzog, Rabbi Walkowsky and "the crème de la crème of Jerusalem's Jews." ${ }^{\text {"1 }}$ Hazofeh, the religious Zionist newspaper, often printed full texts of speeches delivered by HUJ rectors and presidents, noted special events and allowed professors, particularly religious ones, to publish their praise of university activities and support of its students. ${ }^{72}$ The paper devoted extensive coverage to HUJ efforts on behalf of students who had come to Palestine and found themselves without any means of support, having been cut off from their homes by the World War. ${ }^{73}$

At the same time, however, religious Zionists joined forces with Revisionists and the labour movement in attacking what they considered to be dangerous policies pursued by HUJ. In 1938, Hazofeh criticized groups affiliated with HUJ that supported a compromise solution in the Jewish-Arab conflict, claiming that they should not be given access to means for publicizing their views, nor be allowed to negotiate with the British authorities or with the Arabs since doing so would weaken the Jewish position in the conflict. Hazofeh saw supporters of compromise as presenting Zionism in an extremist light and as deliberately blocking a solution while parading as "good Jews" with "progressive ideas." "The Magneses and Bentwiches atop Mount Scopus are sinners who declare a peace that is neither peace nor wholesome. ${ }^{\prime 4}$ The author of the article demanded that these groups cease their activities, especially in light of the imminent visit to Palestine of a special Mandate committee of investigation.

The same writer, Dr. Shmuel Feldmann, authored another article several months later that marked the thirteenth anniversary of HUJ's founding. He described the university's existence as still precarious, noting that even before being built, there were those who raised doubts about the necessity of a university, deeming such a project "a luxury" that could be, and should be, given up. However, now in 1938, HUJ was no longer a luxury since most Central and Eastern European universities were expelling Jews. There was no longer any doubt about the necessity of a Hebrew university. Nonetheless, Feldmann criticized the way HUJ had developed, claiming that it did not serve the needs of the Jewish people. It was meant to create Jewish science, different and distinct from foreign, European science. Since the nineteenth century, numerous Jewish scientists had denied their Judaism, "some of them disguising their Jewish 
names, others leaving the fold and joining - religiously and nationally - the camps of those who hate and ostracize us .... They tried to prove that we are not a nation like all others, and that we ourselves should erase our names from the pages of history. They created whole theories of national, religious, or linguistic denial - sometimes denial of all of them." 75

The purpose of HUJ, according to Feldmann, was to eliminate this "glaring disgrace" by embracing representatives of Jewish political thought. But, HUJ was still far away from realizing this goal. Much of its faculty was belittling Zionism as well as society's needs and ambitions. And then "there are some other blemishes and faults that can be found there." 76 Feldmann concluded that greater public involvement in the university's activities was required in order to correct these failures, which could be achieved through increased effort on the part of political parties and the public at large. This would result in "the construction of a large, glorious building on Mount Scopus...for the kingdom of science. [This building] would be the foundation for building the Jewish Kingdom in the historical boundaries of Eretz Yisrael."77

Scholars of Zionism have usually described a dynamic by which Jewish society gradually established reciprocal relations between the political center and civic and military groups that aspired to recognition, prestige and influence. This reciprocity weakened the critical voice of outside institutions by incorporating them, mobilizing them as part of organized Jewish politics. ${ }^{78}$ This suffocating embrace successfully served the center in neutralizing alternative sources of power and authority in society. However, as we have seen, the myriad attempts to push HUJ into a "proper" course of active cooperation with society, and the vociferous campaign by the national leadership to change HUJ's behavior, all failed. This suggests that while the political center was gaining in strength, its authority was weak, apparently because it remained voluntary, that is, not yet resting on a base of sovereignty. ${ }^{79} \mathrm{HUJ}$, which had exclusive authority over higher education in Jewish society, consistently presented an alternative center of cultural authority, as expressed in the last speech made by its President on the commencement of the 1947 academic year. "Thank God," Magnes exclaimed that day that "we have the Hebrew University here - a haven, a palace, a temple - at least one place were after years of disagreement we are in accord. It seems to me that the university is res republica, an autonomous, independent entity, and dependent neither on state nor ecclesia." 80

\section{Part B}

\section{The Conditions for an Independent University}

This second part of the present article will investigate the two principal forces that encouraged and made it possible for HUJ to maintain ideological and financial independence from its founding until the establishment of the state of Israel.

Two additional factors helped to strengthen the position of HUJ vis-à-vis society. The first was its academic monopoly. Throughout this period, HUJ functioned as a monopoly in the realm of higher education. Although the Technion in Haifa was 
another degree-granting institution of higher learning, there was no overlap between the two schools. Consequently, HUJ constituted the official pinnacle of the Hebrew educational system. In addition, HUJ supervised high-school education and, after 1934, administered its matriculation exams, the latter becoming a condition for acceptance to university. ${ }^{81}$ The monopoly over faculty sources, together with the exclusive right for disseminating scientific and professional knowledge, created an irreplaceable resource, especially in light of the dawning realization of the consequences of the Holocaust for European Jewry.

In addition, HUJ provided cultural inspiration. Many of the immigrants to Palestine saw the university as a significant source of authority in the development of a modern, Western society. This was especially true among the wealthier segments of society in Tel Aviv, Haifa and Jerusalem. Some of the new Jewish immigrants had been raised in Western scientific cultures; some even had academic degrees. ${ }^{82}$ In contrast to societies where the university affects a relatively small portion of the population, HUJ constituted a presence in the consciousness of most of the Jewish public. Thus, for example, parents of urban high school students successfully demanded a system of long-term supervision and control over the schools by HUJ for the purpose of establishing pedagogic standards. The following discussion will focus on the contribution of ideological and financial forces to the ongoing monopoly enjoyed by HUJ during a period of intense nation-building.

\section{B-1: Ideological Independence}

Underneath the cultural and political goal of Zionism in "creating a new Jewish nation and a new Jewish person in Eretz Yisrael" was the desire to release Jewish culture from the essential contradictions of life in the Diaspora. The Jews would return to a pristine condition, a truer existence born of "the Jewish people [living] on its land." The "new Hebrew person" was juxtaposed to the "Diaspora Jew." 83 Political ideologues such as Berl Katznelson and Zeev Jabotinsky called for the creation of a total cultural setting that would rest, among other foundations, on a university. Such a university would need to adapt itself to the requirements of the new Hebrew culture. In 1919, Katznelson wrote that it was incumbent upon Jewish society to build "a system of cultural projects from schools for teaching language to newcomers to creating a Hebrew language for the general population, a good educational establishment, a national art museum and a popular university befitting the local academic needs and the cultural level of the workers of Eretz Yisrael." ${ }^{84}$ During the same year Jabotinsky wrote about the need to "create schools, evening classes, kindergartens, playgrounds, Hebrew-speaking institutions, school books, literature, scientific writing, dictionaries, scientific terminology, maps of the land, a university, an institute of technology, a poly-technological institute, the list is endless." ${ }^{85}$ This culture would manifest the spirit of "a new Jewish society," an "organic," independent society that would reexamine all the fundamental aspects of the human condition, of humanity's relations to nature, to religion, to work, to family, and to Eretz Yisrael and the gentiles. 
This ideological model assumed that the Jews had developed a culture that was unique and independent, distinct from the cultures of those nations where they lived, and this justified the recognition of the Jews as a distinct kulturvolk. Such an identity is based on more than a religious community. It's being crystallized through a Volksgeist, a national spirit expressed in language, history, literature and art. This cultural distinctiveness enables those who share in it to demand political sovereignty over a given territory. ${ }^{86}$ During a period of nation building all centers of cultural leadership, including universities, are expected to devote their energies to disseminating and establishing a national culture. This is done by depicting the antiquity and legitimacy of the nation, emphasizing those characteristics perceived to be original and unique to its culture. Such a task requires the efforts of poets and writers, editors and publishers, teachers and journalists, intellectuals and academics. Divisions of labour are formed in this process of creating national traditions and establishing symbols of collective identity. ${ }^{87}$

In this context, "first tier" culture makers who imbue the nation with unique attributes by means of their originality and creativity fulfill a supremely important role. These include writers, social scientists, historians and archeologists who formulate the contours and basic principles of the collective identity. Together with them a "second tier" of culture makers, teachers, public officials, mass media experts and entertainers are busy at work. Their task is usually seen to be the dissemination and imitation of the "first tier" culture makers. The degree of reciprocity between these two groups influences the depth and intensity by which norms and values spread, especially those related to nation building. ${ }^{88}$ As a creator of corpuses of knowledge and as a training institution, the university fills a pivotal position in the formation of national self-perception.

The successful creation of social and political structures during the period prior to Israel's independence depended on the ability to form a system of governing principles. These principles would undergird both the internal and external operations of these structures that would rest on the ideological distinctiveness of "Zionism." In general, Zionism was the project to create a national Jewish center by means of Jewish immigration to Mandatory Palestine where the Jews would be consolidated into a unique cultural and political community enjoying a modicum of autonomy. This consensual understanding of Zionism was then divided into a large number of political and ideological movements which disagreed over the proper approach for achieving this goal. Ideological distinctiveness allowed the various movements and groups within Jewish society to create separate ecological, cultural and political identities that then anchored their respective demands for autonomy vis-à-vis both the central political leadership and rival structures.

Ideology is a system of ideas that organizes social action devoted to pursuing real goals. ${ }^{89}$ According to this definition, one could say that HUJ made great efforts in emphasizing its ideological independence from the emerging political leadership of Jewish society in Palestine. This independence and its accompanying organizational, cultural and political assumptions, which competed with numerous sectors and political groups constituted a mainstay of the university, specifically from the 1930s until the establishment of the State of Israel in 1948. 
HUJ sought to make itself into an autarchic enclave that offered a unique lifestyle to those under its influence. It should be emphasized that HUJ ideology did not address such narrow issues as academic freedom, that is, freedom of instruction and research within the academy. Rather, ideological independence was manifest in the university's attempt to take part in defining the national and symbolic social order. The culture centers that took shape within the Jewish Zionist population organized around a basic principle: the juxtaposition of Jewish culture in the Diaspora and the Hebrew culture of Mandatory Palestine, together with an ongoing effort to give expression to the unique attributes of "the culture of Eretz Yisrael." This was "one of the factors that united the opposing camps as partners in the creation of Hebrew culture in the Jewish population in the Mandatory Palestine, serving as it did as an ideological foundation and a foundation for cultural consensus that were a prerequisite for most cultural activities." ${ }^{\text {90 }}$

The national ideology celebrated Hebrew culture, which was positive proof of the superiority of the new immigration over the Diaspora. Cultural structures that diverged from this "Hebrew culture" were marginalized and were assigned a negative image, and, at times, even became the target of public opposition. Disengagement from the Eastern European "Diaspora experience" was perceived as crucial for the national project. To this end such concepts as "productivity" and "independent labour" were employed to designate the creation of a productive Jewish economic infrastructure which was independent and unaffiliated, presented as a main condition for establishing the nation. Neither the use of Hebrew nor, living in Mandatory Palestine was in and of itself a recognition of the superiority of the Zionist idea. That idea, rather, derived its strength from the refutation and invalidation of "Diaspora existence." All efforts were consequently aimed at building an inclusive cultural system that would become an alternative to the world that the Jews of Eastern Europe had left behind. In discussing this issue, Ya'akov Shavit, the historian refers to the tension between "Hebrew culture" and "culture in Hebrew."

This tension found intense expression within HUJ, which was the only cultural force in Jewish Palestine that operated in a paradoxical affiliation with the "Diaspora experience." This affiliation being inseparable from its raison d'être. Questions arose about what national or universal content the university should adopt? Who is entitled to define this content? Should HUJ play a role in developing a national ideology, or in educating for national values? Is HUJ a Zionist project or is it a project that belongs to the entire Jewish people (distinct entities according to Zionist ideology)? Is HUJ affiliated with Judaism or with Zionism??2 Most of these dilemmas were expressed in the tension that existed in trying to define the university as a research or a teaching institution, and in the question of whether the national leadership's ethical positions and values obligated other social and political sectors.

The principal issue concerning HUJ's ideological independence was the question of reciprocity between the Jewish center in Mandatory Palestine and Jewish communities in the Diaspora. In other words, what would inform the development of HUJ, the needs of Jewish society in Palestine, defined as the advancement of Jewish nationalism, or the needs of world Jewry, whose commitment to Zionism was feeble? Another ques- 
tion that arose was whether HUJ would become a large public institution offering a haven for students ejected from Europe and, at the same time, a tool for nation building, or a specifically elitist institution that sought to represent the magnificence of Jewish scientific achievement to the world?

Despite clear and prominent voices within the University that called for favoring the needs of Jewish society in Palestine, the dominant approach was an emerging orientation towards world Jewry. This found expression in such declarations appearing in HUJ yearbooks as this one, from 1939:

The Hebrew University of Jerusalem is the one and only university that the Jewish people created for itself. Therefore, it is intended to serve not only the Jewish population in Eretz Yisrael but the entire Jewish people. ${ }^{93}$

This remained the formal position in 1948:

Though the Hebrew University is a vital factor in the cultural and material development of the homeland, it was founded not for Palestine alone, but for the whole Jewish people. The promotion of Hebrew culture throughout the Jewish world is one of its major aims. ${ }^{94}$

The harshest attacks on HUJ portrayed the university as an institution entirely committed to an abstract idea that was divorced from the actual life of Jews in any country. Instead, as this critique continued, HUJ was committed to the values of a universal Judaism and only these values were to determine the course HUJ was to follow. Shmuel Hugo Bergman, ${ }^{95}$ HUJ's first rector, argued that a national university was inseparable from a national revival and the revival of a national language, as was proven by the emergence of new nations throughout the nineteenth century. The founding of HUJ manifested, in addition, the unifying link between the Land of Israel and the Diaspora, giving expression to the desire that:

Jerusalem would become the spiritual center of the entire Jewish people. Ahad Ha'Am's vision of Eretz Yisrael as the spiritual center of the Jewish people was physically manifested by the Hebrew University which must be the university of all of Jewry. ${ }^{96}$

This distinct ideological approach was apparent when compared to most of the other cultural and educational institutions and organizations active in Jewish society in Palestine, which defined their aims as the physical in-gathering of the Jews and focused their efforts on promoting Zionist nationalism in opposition to life in the Diaspora. Despite differences of opinion between various movements, the overriding general goal during the early days of the British Mandate was to create the "New Jew," a person identified with land and nature, "[a] pioneer and hero, a man who renews the bonds between the people and its land in refutation to the Diasporic past. The educational system fostered these views and organized them into a cogent expression of 'Diaspora invalidation' while encouraging all forms of Zionism and all Zionist institutions."97 
HUJ presented a different version of Zionist revolution. While the popular concept envisioned a break between the past and present, a severing of all ties between the old and the new Jew, HUJ promoted a vision of an ongoing bond that could not be severed between the two manifestations of Jewish life, Jewish society in Mandatory Palestine and in the Diaspora. Instead of "Diaspora invalidation," HUJ offered reciprocal integration. In doing so, and through its very presence and isolationism, the university undermined the concept of revolutionary Zionism, especially propounded by the labour movement. Ahad Ha'Am had advanced a similar position at the beginning of the century when he spoke of "founding a large academy in Eretz Yisrael for knowledge or art, and one academy there for language or literature. This is a grand national project that brings us closer to our goal than do one hundred farming colonies." 98

Professor Zeev Brodetsky, who had been a part of HUJ since its inception and who served as the university's President in the early 1950s, emphasized the central role played by the Diaspora in the creation of the HUJ when he catalogued the modern university into two types; "state universities" and "universities of the people." The former were closely supervised by the political leadership, to the point where politicians were responsible for creating committees that then made academic appointments from lists of candidates provided by the political sector. In contrast, universities of the people were born of the public, as when the citizens of a city decide to build a university for themselves. Such universities enjoyed a great deal of independence from political institutions because they refused to include representatives of the public authority in university policy-making bodies. According to Brodetsky, HUJ was fundamentally a university of the people, which meant the Jewish people as a whole and not just those living in Palestine. ${ }^{99}$

Brodetsky further claimed that the term "people's university," when applied to HUJ, was historically unique since its founders did not belong to any specific city or state. Rather, in the case of HUJ, the Jewish people had gathered wherever they happened to be in order to create the university. The HUJ Board of Governors, the university's supreme authority, represented the Jewish people, "and is entrusted with overall supervision for all matters concerning the fundamental path of the university." The Board ratified all important decisions made by the Executive Council and the Senate and "through it the voice of world Jewry can be heard regarding all matters of running its university, and guarantees that the university will continue to be run as the university of the entire Jewish people, not only of the State of Israel." ${ }^{100}$ It may be said that the ideological independence of HUJ gave birth to a heterodox view of some of the central positions embraced by Jewish society in Palestine.

\section{B-2: Financial Independence}

During the period prior to independence the Jewish political leadership in Palestine had access to funds from the world Zionist movement. This was a source of legitimacy and of popular authority. ${ }^{101}$ Negotiations over the allocation of these funds often brought about agreement and cooperation only among the various political parties, but also among sundry financial and social interest groups. ${ }^{102}$ The reciprocal relation- 
ships that took shape between the political establishment and other sectors enabled the former to supply these sectors with material and ethical services and receive in return recognition of its authority as sole representative of the Jewish society. This political authority had both internal and external aspects. ${ }^{103}$

The political leadership center wielded special power within this reciprocity due to its position as the source of resources. It was able to mobilize resources from world Jewry, either in the form of funds (mostly from Jews in the United States) or human resources and legitimization (mostly from Eastern and Central European Jews), a fact that then served as a distinct advantage vis-à-vis other power centers in Palestinian Jewish society. The political leadership's relative weakness due to the absence of a full sovereign was balanced by its increasing control over finances, which became the basis of its social authority.

This financial control strengthened the tendency of the various sectors in Jewish society to assimilate within the national center. This was to be contrasted to HUJ's distinct ideology that rested on the University's financial independence. Since its founding, HUJ had enjoyed financial independence, which allowed it to resist both the political establishment and its organizational allies. ${ }^{104}$

In 1923 to 1925 , the WZO Committee for the university sitting in London was the major source of funding for HUJ. It operated in conjunction with the World Zionist Organization, the Jewish Agency, Keren Kayemet (the Jewish National Fund, or JNF) and Keren Hayesod (the Jewish Foundation Fund). In the years preceding the founding of HUJ, these organizations provided 69.6 per cent of all funds. Out of a grand total of 58.2 thousand Palestine pounds that were raised, ${ }^{105}$ the Zionist organization raised 40.7 thousand. Between 1925 and 1926, with the university's opening, the financial involvement of the Zionist organizations had diminished to a mere 18.2 per cent (or 8.2 thousand Palestine pounds out of a budget of 44.9 thousand Palestine pounds). ${ }^{106}$

The drastic decline in fundraising on the part of Zionist organizations can be explained by the WZO's dissatisfaction with the growing independence of HUJ. Magnes claimed that HUJ must make itself into an independent institution free of any outside influences such as the WZO. He was concerned that Zionist supervision of the university would soon turn it into a state university, thus endangering freedom of research. He declared that HUJ would not become dependent upon any public, social, or political entity that could then dictate its priorities and policies. He consequently objected to giving the World Zionist Organization any say in the university's constitution or in granting it the exclusive power to appoint new governors to the Board. ${ }^{107} \mathrm{~A}$ Board of Governors was formed immediately after the inaugural ceremonies at the university. Nine of its ten members were selected by the WZO. ${ }^{108}$ This body was responsible for HUJ's administration and in particular its finances. The WZO initially sought to transfer all HUJ property and rights to the Board of Governors. At the first meeting of the Board, Weizmann promised that all property owned by the WZO would be transferred to the Board of Governors. ${ }^{109}$ But the move was never approved since the Zionist Congress did not agree with these declarations, and did not insist that the WZO maintain close supervision of HUJ. 
Over time, the Zionist organizations became less involved with the university's budget. During the first decade of operation (1925/6-1936/7), the Zionist contribution amounted to 43.5 thousand Palestine pounds, which constituted 5.7 per cent of the overall budget of 757 thousand Palestine pounds. In contrast, during the same period the Friends of Hebrew University of Jerusalem in the United States contributed 289.7 thousand pounds, or 38.2 per cent of HUJ's budget. This would seem to justify the claim made by Norman Bentwich:

The Hebrew University was the Cinderella of national institutions. The Zionist organizations contributed close to nothing. They believed that the "non-Zionists," who are interested in Jewish culture and in a spiritual center in Eretz Yisrael should supply most of the funds, and Magnes would just get the money by the magic of his words. There was an advantage in that the university was not dependent upon political bodies, but it presented the Chancellor with a heavy burden and a serious responsibility. ${ }^{110}$

The process of creating Friends of the Hebrew University associations in various locales around the world and establishing a fundraising network that was not dependent on Magnes continued for years after the founding of HUJ. ${ }^{111}$ Such associations were founded in any country that had an important Jewish community, and these Friends began to assume a greater share of the financial burden. ${ }^{112}$ An analysis of HUJ income reveals the relative absence of funding coming from the Jewish population of Palestine. The University was entirely dependent upon the generosity of its Friends, as David Werner Senator observed. "There is no other university whose existence relies on relatively small donations by so many people around the world." 113

The HUJ budget grew from 44.9 thousand Palestine pounds in the first year of operations (1925/6) to 98 thousand Palestine pounds in 1936/7. This would seem to be a doubling of the budget. However, growth stopped with the onset of financial crisis in 1929, which especially affected donations from North America. In 1928/9 the HUJ budget was 67.1 thousand Palestine pounds. It declined to 41.1 thousand pounds in $1931 / 2$, a change of some 40 per cent. With the Nazi ascension to power in Germany, donations rose sharply, effectively ending HUJ's financial crisis. In the fiscal year of $1932 / 3$ the budget stood at 43.6 thousand Palestine pounds. In 1934/5 it reached 77.5 thousand Palestine pounds, an increase of 77 per cent.

Because contributions were voluntary, a great deal of uncertainty characterized a major portion of the HUJ budget, which had to be raised anew each year. Worldwide turmoil and financial crises among Jews in many countries made it that much more difficult to obtain the necessary funds. HUJ accordingly sought to create a situation in which a permanent endowment would finance most of the budget. This would then ensure a permanent, orderly budget for the university while granting it financial independence, independence even from the associations of Friends.

Several factors combined to bolster HUJ's independence. First, the WZO and its various sources of funds effectively ceased extending support to the university. Second, HUJ raised funds from a relatively large number of supporters around the world. 
Third, because the Friends' associations were geographically dispersed, organizational links between them were weak, keeping them from effecting any immediate supervision of the university. Fourth, HUJ did not have one major source of financial support, such as a large corporation, benefactor, or state, which could then wield a great deal of power over matters of fundraising. In addition, the Board of Governors convened annually in the interwar period, meeting twelve times between 1925 and 1936. However, with the onset of World War II, the Board was unable to gather, which left HUJ Executive Committee to shoulder both all the responsibility and authority. In reality, it was the senior academic faculty, through the University Senate and its committees, which supervised and controlled academic activities, finances and the university culture. All these factors meant that the academic faculty at HUJ enjoyed a great measure of autonomy in guiding the development of the university. ${ }^{114}$

\section{Conclusion}

This article has examined the distinct path by which a national university was founded and developed in a period of intensive nation-building. Instead of the more common pattern of close cooperation and solidarity characteristic of relations between the national political leadership and the university, which is seen to be a flagship institution in the national struggle, we have found a significantly different dynamic at work: consistently bitter attacks by all of society's political parties and cultural movements that were aimed at the university. They constituted a "united front" opposed to the direction pursued by HUJ during the years prior to statehood. This confrontation revolved around a broader issue concerning the boundaries of the "imagined community" of the Zionist movement. ${ }^{115}$ Is a Jew living in New York, London, or Warsaw with no intent to immigrate to his historical homeland a part of the national project? Is the role assumed by the Jews of the Diaspora limited to contributions of financial resources, or does it include the right to help shape the identity of the national movement? The debate over the involvement of Jewish communities in the leading cultural project of the pre-state era, namely, the development of the Hebrew University, was precisely about expanding the boundaries of the Zionist program. It should be noted that the creation of a national university was not analogous to a business investment designed to yield profits, or to a charitable contribution directed to the needy. The founding of a university in Jerusalem, rather, manifested an ambition to influence the very foundations of Jewish national thought.

As such, it is easy to understand the criticisms voiced by David Ben-Gurion, Menachem Begin, Zeev Jabotinsky and Berl Katznelson. These political leaders were not opposed to the notion of a Jewish university, an institution they considered in fact to be important and even critical to national success. At the same time, they were apprehensive about the enormous influence Jewish communities from around the world wielded in the creation of an alternative cultural center that was liable to weaken their own political and social authority precisely during a period when they struggled to achieve a practical legitimacy that could not yet rest on actual sovereignty (which was in the 
hands of the British Mandatory authorities). ${ }^{116}$ In fact, such a challenge did take place. HUJ consistently refrained from devoting itself to the needs of Jewish society in Palestine, particularly in the sphere of professionalism. It refused to open either a law faculty or departments in the social sciences. Nor was a faculty of agronomy opened until, following a long drawn-out struggle, a modest department of agriculture was established that set its academic standards high enough in order to limit the number of students qualified to enroll in its program and so keep out "simple" farmers in need of short-term courses or professional training. Demands to open a Tel Aviv branch of the University likewise provoked strong opposition and were successfully frustrated. ${ }^{117}$ The same fate met demands to establish a chair in Zionist studies.

HUJ saw itself as, first and foremost, an institution serving the Jewish people as a whole and not just the needs and interests of Jewish society in Palestine. This sense of its mission was largely based on the thought of Ahad Ha'Am, who posited a dissident Zionist view of the tension and formative discourse existing between the Jewish society in Palestine and the Diaspora. This belief system was practically consolidated by means of independent financial sources which allowed the University to operate as an autonomous entity, and which kept it from integrating into political movements and other social formations. HUJ was thus able to escape the widespread politicization of the country's educational system during this era of intensive nation building.

\section{Notes}

1 Assaf Likhovski, Law and Identity in Mandate Palestine (Chapel Hill, NC: University of North Carolina Press, 2006), Chs. 3-4; Carl Alpert, The Technion: The Story of Israel's Institute of Technology (New York: American Technion Society, 1982), 17-145; Uri Cohen, "The School of Law and Economics in Tel-Aviv, 1935-1948: The Hopeless Pursuit of Political-Academic Legitimacy," Mechkarei Mishpat, The Faculty of Law, Bar Ilan University, forthcoming (Hebrew).

2 Letter from David Ben-Gurion, acting prime minister, to the administration of the Hebrew University, 8 August 1948, The National Archives of Israel, 3653/5544/C.

3 The Hebrew University of Jerusalem, 1960 (Jerusalem: Hebrew University Press, 1960), 5-9, 210-213 (the yearbook of the HUJ).

4 Shaul Katz and Michael Heyd, eds., The History of the Hebrew University of Jerusalem: Origins and Beginnings (Jerusalem: The Magnes Press, 1997), (Hebrew). Hagit Lavsky, ed., The History of the Hebrew University of Jerusalem: A Period of Consolidation and Growth (Jerusalem: The Magnes Press, 2005), (Hebrew).

5 David N. Myers, Re-Inventing the Jewish Past, European Jewish Intellectuals and the Zionist Return to History (New York \& Oxford: Oxford Press, 1995).

Also in: David N. Myers, 'A New Scholarly Colony in Jerusalem: The Early History of Jewish Studies at the Hebrew University', Judaism, 45, 2 (Spring 1996): 142-159.

6 Harold Gordon Skilling, 'The Partition of the University of Prague', The Slavonic and East European Review, 27 (1948/49): 430-449; Shmuel Noah Eisenstadt and Stein Rokkan, ed., Building states and nations (Beverly Hills [Calif.]: Sage Publications, 1973); Stein Rokkan, "Dimensions of State Formation and Nation-Building: A Possible Paradigm for Research on Variations within Europe" in Charles Tilly, ed., The Formation of National Sates in Western Europe (Princeton, NJ: Princeton University Press, 1975), 562-600; 
Martha Hanna, The Mobilization of Intellect: French Scholars and Writers during the Great War (Cambridge, MA: Harvard University Press, 1996).

7 Gwynn J. Williams, The University College of North Wales: Foundations 1884-1927

(Cardiff: University of Wales Press, 1985);

Paul T. Durbin, ed., A Guide to The Culture of Science, Technology and Medicine (New

York: The Free Press, 1980), 31-33;

Ronald Charles Tobey, The American Ideology of National Science, 1919-1930

(Pittsburgh: University of Pittsburgh Press, 1971);

Robert Jackson, "The Universities, Government and Society" in David Smith and Anne Karin Langslow, The Idea of A University (London; Philadelphia: J. Kingsley Publishers, 1999), 91-105.

8 John E. Craig, Scholarship and Nation Building, The Universities of Stasbourg and Alsatian Society 1870-1939 (Chicago: University of Chicago Press, 1984), 1.

9 Anthony D. Smith, The Ethnic Origins of Nations (Oxford: Blackwell Publishing, 1988), 157-161.

10 Martin Buber, Berthold Feiwel, Chaim Weizmann, Eine Judische Hochschule (Jerusalem: Magnes Press, 1968 [1902]), (Hebrew).

11 Ilan Troen, "Higher Education in Israel: an Historical Perspective," Higher Education 23, 1 (January, 1992): 45-63.

Joseph Ben-David, "Universities in Israel: dilemmas of growth, diversification and administration," Studies in Higher Education, 11, 2 (1986): 105-130.

12 From its founding, the University announced that students of both sexes and all races, nationalities, and creeds were eligible for admission to the HUJ. The use of Hebrew as the medium of instruction in the University was, in its first decade, both a matter of policy and of practical necessity since Hebrew had become the mother tongue of the Jewish population in Palestine. The following passage is quoted from Dr. Judah Leib Magnes, who spoke at the inauguration of the Institute for Jewish Studies on 22 December 1924: "The Institute is open to every man and woman without reference to their religion, race, or nationality.... The teaching language is Hebrew." Judah Leib Magnes, The Speeches of the Chancellor of the Hebrew University (Jerusalem: Hebrew University Press, 1936), 4. The Chancellor also declared in another speech delivered in New York on 5 May 1924: "The fourth characteristic of the Hebrew University is found in the fact that, as Jews, we must fill the role as mediators between East and West. We aspire to establish an important research center devoted to Islam and the East and we want to locate it within our institution, a place where both teachers and students will not all be Jews, and could even be our Muslim brothers.” Magnes, Speeches, p. 11.

13 This argument contradicts the statements common in Critical Sociology, e.g., U. Ram, "Society and social science: sociology of the establishment and critical sociology in Israel" in Israeli Society: Critical Aspects, ed. Uri Ram (Tel-Aviv: Brerot press, 1993), 7-39 (Hebrew).

14 Israel Kolet, "The Idea of the Hebrew University in the Jewish national movement" ed. S. Katz and M. Heyd, The History of the Hebrew University of Jerusalem - Origins and Beginnings (The Magnes Press, Jerusalem), 3-75 (Hebrew).

15 Reuven Cahanne, "Attitudes of Dominant Ideologies toward Science, Scientists and Professionals in the yishuv period," Shmuel Noah Eisenstadt, Rivka Bar-Yosef, Reuven Cahanne, eds., Strata in Israel (Jerusalem: Academon Press, 1968), 181-236 (Hebrew).

16 For a discussion of the varieties of thought within the Zionist movement during the prestate era see Walter Laqueur, A History of Zionism (London: Weidenfeld and Nicolson, 1972); Gideon Shimoni, The Zionist ideology (Hanover, NH: University of New England Press) 1995; On the political and social structure, the important study is Dan Horowitz, Moshe Lissak, Origins of the Israeli polity: Palestine under the mandate (Chicago: University Press of Chicago, 1978). 
17 Eran Kaplan, The Jewish radical right: Revisionist Zionism and its ideological legacy (Madison, Wis.: University of Wisconsin Press, 2005).

18 Zeev Jabotinsky, Autobiography (Jerusalem: Ari Jabotinsky press, 1958), 88-89 (Hebrew).

19 Abraham David Gordon, Gordon's Writings: Nation and Labor (Jerusalem: Jewish Agency, 1952), 442-443 (Hebrew).

20 Yosef Aharonovitz, "To the Congress," Hapeol Hatzair [The young worker] 5, 38/39, 18 July, 1913 (Hebrew).

21 Eliezer Vulcani, "University," Ha-Achdut [The Unity] 38, 1913 (Hebrew).

22 Beer Borochov, Writings, vol. 3 (Tel-Aviv: Ha’Kibutz Ha’Mehuchad, 1955), 776 (Hebrew).

23 This refers to Churchill's White Book of 1922, published after the riots in Jerusalem in 1920, and in Jaffa and several other locations in 1921.

24 Zeev Jabotinsky "Individual opinion," in The Zionistic Revisionism in formation, Zeev Jabotinsky, a collection of articles in Razsvet from 1925-1929. Ed. and Preface, Yehuda Nedava (Tel Aviv: Jabotinsky Institute, 1985), 63 (Hebrew).

25 Ibid., 64.

26 Ibid., 65.

27 Ibid., 66.

28 Zeev Jabotinsky, “Unanimity,” Ibid.,80.

29 Zeev Jabotinsky, "Speaking of the University," Ha'aretz, 4 August, 1924 (Hebrew).

30 Ibid.

31 Ibid.

32 "Revisionist Escapades," Davar, 14 March, 1937 (Hebrew).

33 Yavneh and Yodfat, Manifest, National student league of the Hebrew University, No date, Hahagana archive, file no. 20/86 (Hebrew).

34 It may be assumed that the pamphlet Ladror expressed the Revisionists' positions. For instance, the poem "Goblet" appears at the beginning of the third issue (August 1942) to mark the day of Jabotinsky's death, and following that - segments of his thoughts. The same publication, in the second issue (November 1943), contained a poem by Uri Zvi Greenberg "One Truth, Not Two"(Hebrew).

35 "In Beit-Hakerem high school," Hadror, 1, 3 (August 1942), Hahagana archive, file no. 20/86 (Hebrew).

36 "On the Margins of One Case," Ibid. (February 1943, Hebrew).

37 Menachem Begin, "The voice of a child," Herut [Liberty] 48, 5 July, 1945, 2 (Hebrew).

38 Bustenai, 41 (22 January, 1930), 6 (Hebrew).

39 Bustenai, 18 (7 August, 1929), 5 (Hebrew).

40 Bustenai, 43 (2 April,1930), 6 (Hebrew).

41 The University's first faculty that of the humanities was founded in 1928 and consisted of three divisions: the Institute of Jewish Studies, the School of Oriental Studies, and courses in General Humanities. The Institute of Jewish Studies offered a course of study comprised of Bible, Talmud and Jewish jurisprudence, Hebrew language and literature, Palestinology, Jewish philosophy and mysticism, Jewish history and sociology and Hebrew archaeology. The School of Oriental Studies focused on the study of the art and archaeology of the Near East, together with Arabic language, literature, history and philosophy. The Institute of Jewish Studies was considered a unique institution within the HUJ: "This Institute is the only one within the Hebrew University to enjoy academic autonomy. The exceptional position of the Institute is indicative of the exceptional character of the studies to which it is dedicated. Zionists may differ from non-Zionists, Zionists may differ among themselves on the necessity or even the desirability of a university in Palestine; there can, however, be only one view concerning the dire need for a House of Jewish Learning on the soil from which it sprang... The Institute of Jewish Studies 
attempts to satisfy the demand of "All-of-Israel." Report of the Survey Committee of the Hebrew University, the Sir Philip Hartog committee, 1934, p. 16. The report was defined as "private and confidential" - for members of the board of governors only.

For more about this issue, see David N. Myers, "A New Scholarly Colony in Jerusalem: The Early History of Jewish Studies at the Hebrew University," Judaism, Issue No. 178, Vol. 45, Number 2, Spring 1996, pp. 142-159; see also Shelomo Dov Goitein, "Oriental Studies in Israel," in Norman Bentwich, ed., Hebrew University Garland - A Silver Jubilee Symposium (London: Constellation Books, 1952), pp. 96-110.

42 Moshe Smilansky, "Second Graduating Class at the Hebrew University," Bustenai, 38 (4 January, 1933), 6-7 (Hebrew).

43 Ibid.

44 "The university and the Jewish student," Bustenai, 9 (14 June, 1933), 6 (Hebrew).

45 Ibid.

46 Ibid.

47 Moshe Smilansky, "Einstein and the university," Bustenai, 13 (12 July, 1933), 7 (Hebrew).

48 Moshe Smilansky, "The opening of the university," Bustenai, 30 (15 November, 1933), 5 (Hebrew).

49 Aron Gertz ed., Statistical Handbook of Jewish Palestine, Jerusalem (The Jewish Agency of Palestine, 1947), 46-47 (Hebrew).

50 Moshe Smilansky, “The Demonstration on Mount Scopus”, Bustenai, 27 (24 October, 1934), 7.

51 Moshe Smilansky, “In the University," Bustenai, 44 (02.19.1936), 7 (Hebrew).

52 Haiaretz," 23 October, 1937 (Hebrew).

53 Moshe Glickson, "Timely Questions," Ha'aretz, 3 May, 1937 (Hebrew).

54 Ibid. It appears that the words were directed at Prof. Richard (Michael) Koebner (18851958), a Jewish historian born in Germany (Breslau). Koebner received his doctorate in Berlin in 1911. In 1920, he became a lecturer at the University of Breslau and in 1924 became a professor. With the rise of the Nazis he was forced to leave his position and came to Jerusalem. In 1934, he became a professor at HUJ and was Head of the General History Department until his retirement in 1955. Koebner, who was torn out of his spiritual homeland, did not get accustomed to the local lifestyle and had difficulties conversing in Hebrew. Yehoshua Arieli, "History and Historical Consciousness in Richard Koebner Thought," eds. Shaul Katz and Michael Heyd, (see note no. 2), 541-574 (Hebrew).

55 Avraham Levinson, "Our Duty to the University," Davar, 11 February, 1937 (Hebrew).

56 For a broader scope on Katznelson's standing in the Labor Movement see Anita Shapira, $\operatorname{Berl}$ (Tel Aviv: Am Oved, 1980), (Hebrew).

57 Berl Katznelson, "The University Developing," a speech given at the general assembly of the Friends of Hebrew University in Tel-Aviv, 5 December, 1935, Berl Katznelson, The words of Berl Katzenelson on the Hebrew university (Jerusalem: Achva Printing, 1945), 2.

58 Ibid., 5 .

59 Ibid., 7.

60 Ibid., 8-9.

61 Ibid., 12.

62 Ibid., 15.

63 Berl Katznelson, "Science-workers at the Service of the Nation," Closing speech given at a party held at Mount Scopus by the university science workers on the occasion of joining the Federation of Clerks, Shurot, Newspaper of the Central Federation of Clerk, 42, September 1944 (Hebrew). 
64 Ibid., 41.

65 David Ben-Gurion (1886-1973); Ben-Gurion was a founder of the trade unions and in particular the national federation, the Histadrut, which he dominated from the early 1920s. He also served as the Histadrut's representative in the World Zionist Organization and Jewish Agency and was elected chairman of both organizations in 1935. Having led the struggle to establish the State of Israel in May 1948, Ben-Gurion became Prime Minister and Defense Minister.

66 David Ben-Gurion, Speech at the third student conference in Tel-Aviv (January 1944); the full speech may be found in the Ben-Gurion Seminary, Sde-Boker (Hebrew).

67 David Ben-Gurion, "A letter to the sixth MAPAI convention," Davar, 8 September, 1946 (Hebrew).

68 H. Rabinovitsch, "In life and in literature," Hayesod, General Orthodox Weekly, April, 1938 (Hebrew).

69 Ibid.

70 D. Yanovsky, "Yavneh League of Religious Students in Jerusalem," Hatzofeh, 2 February, 1938 (Hebrew).

71 Ibid.

72 "Speech of the University Rector, Prof. Avraham Halevi Frenkel at the Graduation Ceremony," Hatzofeh, 5 May, 1940; "Words of the President of the Hebrew University of Jerusalem at the End of the School Year," Hatzofeh, 3 July, 1940; "A Holiday on Mount Scopus," Hatzofeh, 1 May 1940; S. Klein, "The Institute for Sciences of Judaism at the Hebrew University of Jerusalem," Hatzofeh, 14 October, 1938; Avraham Halevi Frenkel, "Natural studies and the Jewish Torah at the Hebrew University of Jerusalem," Hatzofeh 14 October, 1938 (Hebrew).

73 "University's Activities for the Students in 1940," Hatzofeh, 4 July, 1940; "University and Students," Hatzofeh, 4 July, 1940 (Hebrew).

74 Dr. Shmuel B. Feldmann, "Those Who Give Up," Hatzofeh, 13 January, 1938 (Hebrew).

75 Dr. Shmuel B. Feldman, "A Hebrew University - For What?" Hatzfeh, 4 October, 1938 (Hebrew).

76 See above, Note 65.

77 Ibid.

78 Uri Ben-Eliezer, Through the viewfinder - the formation of Israeli militarism 1936-1956 (Tel Aviv: Dvir, 1995), 309-315.

79 Shmuel Hirsh and Uri Cohen, "Critical Sociology in Israel - A Reinterpretation," Iyunim Bitkumat Israel, 10 (2000): 317-352 (Hebrew).

80 Yehuda Leeb Magnes, “The Hebrew University and Its Role," in Magnes, Jehuda Leib, Collection of Ideas and Expressions (Jerusalem: The Hebrew University, 1949), 10 (Hebrew).

81 In 1929 the British authorities unilaterally withdrew their recognition of diplomas issued by Jewish academic high schools in Palestine as being equivalent to the matriculation examinations given throughout the empire. The British now demanded that Jewish students study a curriculum determined by the imperial administration which would be taught in English and would incorporate English subjects. Such steps were adamantly opposed by the principles of the Jewish schools. This withdrawal of recognition was especially injurious to youngsters who hoped to continue their academic studies in Europe or the United States. As a consequence, an appeal was prepared by the education department of the World Jewish Committee to the Hebrew University asking that the university oversee and sponsor the high school diplomas. After an extended negotiation, an oversight committee was established which was active from 1934 until the creation of the state of Israel in 1948. The majority of the committee's members were academics from the Hebrew University. Likewise, the committee's chairman was from the University, 
Professor of Mathematics Abraham Halevi Frankel. The committee exercised close control and supervision over the educational practices and curriculum of the high schools, which included the demand that all teachers be credentialed in the fields in which they taught. All oral examinations were done away with, as were exams based on summaries of the material. Each year, each school was visited and evaluated by representatives of the university who came to ascertain whether the school's level qualified it to be included under the committee's purview. For more on the subject see Asher Reshef and Yuval Dror, Hebrew Education during the period of National Home, 1919-1948 (Jerusalem: Mosad Bialik, 1999) (Hebrew).

82 About 12 percent of all arriving immigrants in 1932-1942 were academic professionals. David Gurevitz, Aron Gertz, and Roberto Bachi, The Yishuv and Natural Population Movement in Eretz Yisrae. (Jerusalem: The Statistics Bureau of the Jewish Agency, 1945), Table 25, 72 (Hebrew).

83 Itamar Even-Zohar, "The Growth and Formation of Local and Native Hebrew Culture in Eretz Yisrael, 1882-1948," Catedra 16 (July 1980): 165-189 (Hebrew).

84 Berl Katznelson, “Toward Forthcoming Days," (1919). The Writings of Berl Katznelson (Tel Aviv: Mapai, 1945), 85-86 (Hebrew).

85 Zeev Jabotinsky, "Work and Mood," Hadshot Hảaretz 27 Oct. 1919 (Hebrew).

86 Ya'acov Shavit, "The Status of Culture in the Process of Creating a National Society in Eretz Yisrael: Basic Attitudes and Basic Concepts," Zohar Shavit, ed., History of the Jewish yishuv in Eretz Yisrael since the First Aliyah: Constructing a Hebrew Culture in Eretz Yisrael, Part I (Jerusalem: The Israel Academy for Sciences and Humanities and The Bialik Institute, 1998), 9-29 (Hebrew).

87 Edward Shils, 'Intellectuals, Traditions, and the Traditions of Intellectuals: Some Preliminary Considerations', in Shmuel Noah Eisenstadt and Stephen Richards Graubard, eds., Intellectuals and Tradition (New York: Humanities Press, 1973), 21-34.

88 Shmuel Noah Eisenstadt, Luis Roniger and Adam Seligman, Centre formation, protest movements, and class structure in Europe and the United States (London: F. Pinter, 1987).

89 Martin Seliger, "Fundamental and Operative Ideology: The Two Principal Dimensions of Political Argumentation," Policy Sciences, 1, 1 (March, 1970): 325-338.

90 Zohar Shavit, 'Introduction,' in (ed.) Zohar Shavit, History of the Jewish yishuv in Eretz Yisrael since the First Aliyah: Constructing a Hebrew Culture in Eretz Yisrael, Part I

(Jerusalem: The Israel Academy for Sciences and Humanities and The Bialik Institute, 1998), 3 (Hebrew).

91 Yàacov Shavit, "The Status of Culture in the Process of Creating a National Society in Eretz Yisrael," note 85.

92 Michael Heyd, "Outlining the Initial History of the Hebrew University," eds. Rivka Feldhay and Imanuel Etkes, Education and History (Jerusalem: Zalman Shazar Center, 1999), 355-375 (Hebrew).

93 The Hebrew University of Jerusalem: Formation and Situation (Jerusalem: The Hebrew University Press, 1939), 16 (Hebrew). Magnes, HUJ Chancellor declared in New York in May 1925 that "the university does not belong only to Eretz Yisrael, but belongs to the entire Jewish people." Yehuda Leeb Magnes, Compendium of Ideas and Sayings (Jerusalem: The Hebrew University Press, 1949), 3 (Hebrew).

94 The Hebrew University - Jerusalem: Its History and Development (Jerusalem: The Hebrew University Press, 1948), 16.

95 From 1920-1935 Bergman served as Director of the National and University Library in Jerusalem. He was appointed Professor of Philosophy and nominated as the first Rector in 1935, after the position of University Chancellor (which combined academic and administrative responsibilities) had been eliminated. Bergman served as Rector from the end of 1935 to 1938, when he was replaced by Prof. Abraham Halevy Frankel. 
96 Samuel Hugo Bergman, "A Vision for the Future of the Hebrew University," Haim Toren, ed., The Hebrew University of Jerusalem: 25 Years 1925-1950 (Jerusalem: The Hebrew University Press, 1950), 131-134.

97 Asher Reshef and Yuval Dror, Hebrew Education during the period of National Home, 1919-1948 (Jerusalem: Mosad Bialik, 1999), 171-172 (Hebrew).

98 Ahad Ha'Am, "Revival of the Spirit," Writings of Ahad Ha'Am (Tel Aviv: Dvir, 1947), 173-186 (Hebrew).

99 Zeev (Selig) Brodetsky, "People's University," in Haim Toren, ed., The Hebrew University of Jerusalem: 25 Years 1925-1950 (Jerusalem: The Hebrew University Press, 1950), 65. While serving as President of the University after the founding of the state, Professor Brodetsky sought to free the Hebrew University, the Technion in Haifa and the Weizmann Institute from governmental oversight by means of direct and massive fundraising among world Jewry on behalf of higher education. The target sum would be 7.5 million dollars a year with support of Professor Albert Einstein. As Brodetsky declared: "The University must face the responsibility of refusing to produce a student proletariat, and of increasing the laboratory space for subjects on which the development of Israel depends, now and for a long time to come. This means a constant struggle with the Israeli Government in regard to space and the material and cost of building." Selig Brodetsky, "Development of the Hebrew University," Norman Bentwich, ed., Hebrew University Garland - A Silver Jubilee Symposium (London: Constellation Books, 1952), 124.

100 Zeev (Selig) Brodetsky, "People's University," in H. Toren, ed., The Hebrew University of Jerusalem: 25 Years 1925-1950 (Jerusalem, The Hebrew University Press, 1950), 66.

101 Yigal Elam, The Jewish Agency, Formative Years: 1919-1931 (Jerusalem: Hassifriya Haziyonit, 1990).

102 Benjamin Eliav, The Jewish National Home: from the Balfour Declaration to Independence, (Jerusalem: Keter Publishing, 1976), 136-194.

103 Jacob Metzer, The divided economy of Mandatory Palestine (Cambridge: Cambridge University Press, 1998).

104 Ruth Klinov, "Governance and Finances of the Hebrew University, 1923-1947," in Hagit Lavsky, ed., The History of the Hebrew University of Jerusalem: A Period of Consolidation and Growth (Jerusalem: The Magnes Press, 2005), 71-112 (Hebrew).

105 The Palestine Pound was equivalent to British Sterling.

106 These data are based on income charts, arranged by year and source of income for the years 1923-1925 and 1936-1937. Sums are quoted in Palestinian pounds Hebrew University of Jerusalem (see Note 17), 112-113 (Hebrew).

107 Bezalel Barshai, “The Hebrew University of Jerusalem, 1925-1935,” Katedra 53 (1990): 107-112 (Hebrew).

108 The nine were Ahad Ha'Am, Weizmann, Magnes, Albert Einstein, Chaim Nachman Bialik, Felix Warburg, Sir Alfred Mond, Nahum Sokolov, and James De Rothschild.

109 Minutes of the Board of Governors' first meeting, Tel Aviv 12 April, 1925, 1-2. University Archives, File 16 (Hebrew).

110 Norman Bentwich, For Zion's Sake: A Biography of Dr. J. L. Magnes (Jerusalem: Magnes Press, 1956), 113 (Hebrew).

111 Eliyahu Honig, "The Societies and Finances of the Hebrew University, 1925-1948," in Hagit Lavsky, ed., The History of the Hebrew University of Jerusalem: A Period of Consolidation and Growth (Jerusalem: The Magnes Press, 2005), 113-145 (Hebrew).

112 David Werner Senator, "History of the Hebrew University 1935-1947," in H. Toren, ed., The Hebrew University of Jerusalem, 25 Years, 1925-1950 (Jerusalem, 1950), 55 (Hebrew).

113 Ibid., 53-56.

114 For a discussion of the administrative apparatus of HUJ, see Uri Cohen, "Governing Institutions of the Hebrew University, 1925-1948,” in H. Lavsky, ed., The History of 
the Hebrew University of Jerusalem: A Period of Consolidation and Growth (Jerusalem: The Magnes Press, 2005), 3-70 (Hebrew).

115 Benedict Anderson, Imagined communities: reflections on the origin \& spread of nationalism (London: Verso, 1999).

116 Dan Horowitz and Moshe Lissak, Authority without sovereignty: the evolvement of the national centre of the Jewish community in Palestine (Jerusalem: Office for Overseas Students, Hebrew University, Department of Sociology, 1970).

117 Uri Cohen and Dana Katz, "Friends of the Hebrew University in Tel-Aviv, 1933-1940: Urban Culture Based on an Academic Identity," Israel, 8 (2005): 1-38 (Hebrew). 